\title{
A Fuzzy MCDM Approach for Evaluating Listed Private Banks in Tehran Stock Exchange Based on Balanced Scorecard
}

\author{
Mansour Momeni \\ Associated Professor of Tehran University, Tehran, Iran \\ E-Mail: mmomeni@ut.ac.ir \\ Mohammad Hassan Maleki \\ PhD Candidate of Operation Research, University of Tehran, Tehran, Iran \\ E-Mail: momaleki@ut.ac.ir \\ Mohammed Ali Afshari (Corresponding author) \\ Master of Operations Management, Kar University, Qazvin, Alborz Industrial City, Iran \\ Tel: +98-938-202-9618Ｅ-mail: mohamadaliafshari@yahoo.com \\ Javad Siahkali Moradi \\ Master of Operations Research, Science and Research University, Tehran, iran \\ E-mail: syahkaly@yahoo.com \\ Javad Mohammadi \\ Master of Business Management, University of Tehran, Iran \\ E-mail: javadmohammadi10426@yahoo.com
}

Received: November 22, $2010 \quad$ Accepted: December 23, 2010 doi:10.5430/ijba.v2n1p80

\begin{abstract}
In today competitive world, banks in order to promote and progress should constantly utilize approaches and patterns for evaluating their function in organization. Concerning the importance of discussion, evaluating banks functions seems to be necessary for using an approach in order to determine all criterions and key factors. Thus, in resultant research of this article, balanced score card model was implemented. In resultant research of this article, firstly, four aspects of BSC for evaluating and assessing banks have been designated through studying perspectives, missions, solutions, banks' aims, overview of research literature, criterions, and sub criterions and then gravity of every criterion and sub criterion was determined by newspapermen help being specialized in the field of banking. And after gathering data related to every criterion, decision matrix was formed and banks were ranked by utilization of SAW, VIKOR, and TOPSIS techniques. Whereas it was possible that the methods results would be different, in the final step, borda method was embraced for consolidation of resultant outcomes and final ranking. In this research, Parsiyan bank got first rank, and Eghtesade Novin bank, KarAfarin Bank got second and third ranks respectively.
\end{abstract}

Keywords: Performance measurement, Balanced scorecard, Private banks, Techniques of TOPSIS, VIKOR, SAW

\section{Introduction}

In this period, agencies, different industries and even countries encounter with situations and challenges have influenced on their business and threatened their life in the field of economy and business, globalism of business, complication and growth of consumption markets and increase of fast changes in consumption and demand samples, are the types of threats and opportunities with which agencies encounter.

In such situations and spaces, the main question is that what is the resistive and survival secret of agencies and industries in the field of business? And principally, what factor, index or, more important, managing and control systems provide situation of competitive benefits for organizations beside each other? 
Organizations due to determine their position and improvement in today competitive world, should use methods and patterns in order to evaluate and improve their continuance application and current activities in organization.

Measurement systems of organizations' Performance that are to control consistency of organization's plan and activities having commission and perspective for determining organization's growth and movement and to get competitive benefit in growth and success processes and indexes, today are the most important plans and functions of progressive organizations that ascertain their strategic goals by effective and precise control of their activities and processes in all aspects (financial and procedurals).

\section{Literature Review}

\subsection{Performance Evaluation}

From the formation of management science and contextual evolution of work and organization division, terms of control and supervision were continually used in management literature. Totally, evaluative system of Performance can be understood as a systematic process of measurement and comparison of quantity and achievement way to particular situation. In fact, it is a comparison between whatever is existed and whatever is particular.

Although, new science of current management doesn't breach processes of control and supervision by traditional way, but changes in principal context and effect of different political and economical variables of the world have replaced new methods.

Today, intellectuals and managers of organization found that traditional systems of performance evaluation having been typically based on financial views are incomplete in evaluating Performance of organization and presenting effective feedback (Andersen, 2006).

Traditional method of measurement of net sales and like it was used for measuring Performance. This financial data due to definite and real extent have advantages, but there are important reasons beside such measurements which are as following:

1. Financial measurements present summary of organization's activities in last period, even by presentation of the best sample of performance results, it is not a reason for continuity of these results in the future.

2. Excessive financial measurements effects on short-term profit and loss of organization and regards all relative proceedings of reducing expenditure and increasing income positively. While most of expenditures' reduction (like reduction of educational programs) increases organization's profit, but bring about losing competitive situation and threatens long-term profit. Principle power of valuation in organization is in intangible assets (knowledge and ability of personals, relationship with customers and suppliers) and financial aspect is not able to evaluate intangible assets (Kravchuk \& Schack, 1996).

\subsection{Performance evaluation of banks and financial institutions}

In current economic literature of the world, financial systems, currency markets as well as finance and credit institutions being as administrative arms of this system and instrument of growth and economic development of countries are tangible, so that resistant development of economy without growth and development of financial markets is not possible. Hence, finance and credit organizations possess the pivotal rule in this field (lebas, 1995).

Traditional hierarchy is utilized on performance evaluations of banks on the basis of easy and consistent factors like return on assets (ROA) and return on investments (ROI). However, this hierarchy of fulfilled performance in this method is possible that to don't precisely show institutions being involved in strategies for getting high performance (Hanley \& Suter, 1997).

Non-financial criterions like customer's satisfaction and relationship between employers can be necessary for strategic success of bank, since using criterions as ROA and ROI don't determine hierarchy of performance as what bank present more return on capital. Performance evaluation of banks can be very different and variant (Kosmidou, \& Zopounidis, 2006).

Previous studies of evaluating banks and economic criterions used traditional-statistical methods as associational analysis, coverage analysis of data and other instruments (Arshadi \& Lawrence, 1987).

All finance and credit institutions like banks evaluate their performances on the basis of financial indexes and don't pay attention to other indexes like employees' satisfaction (customer and investor), internal processes of organization and even other indexes like level of employees' income (Schaffnit,1997).

Mayer (1007) arranged principle factors of success of evaluating banks in 8 groups: 1. Profitability; 2. Efficiency and productivity; 3. Human resource management; 4 Risk management; 5. Sales effectiveness; 6 . Service quality; 7. Capital management; 8. Competitive positioning (Meyer \& Markiewicz,1997) 
Coiler (1995) used some of structural equation models in order to assess performance process of banks by criterions like process quality errors, employee turnover rate, on-time delivery and employee efficiency (Collier,1995).

Utilized indexes by Lavens (1987) include profitability, price of bank services, and share of local market. In accordance with literature of analysis, selective criterions which customers use for evaluation of banks include price, speed, achievement, customer service, place, credit and popularity, new facilities, interest rate, time of giving service and banking incentives (Anderson \& Fulcher, 1976).

\subsection{Balanced scorecard}

Balanced scorecard is one of the most important posed instruments in the field of business in the last century. In the beginning of 1990, Robert Kaplan, professor of commercial academy of Harvard University along with David Norton being manager of a research company in this time, began a research program in order to assess successes factors of 12 top American companies and to study performance evaluation of these companies. Thus, Kaplan and Norton announced that due to do a complete evaluation of performance, performance of the organization should be evaluated in four perspectives:

1. Financial Perspective, 2 .Customer Perspective, 3.Internal Processes Perspective, 4.Learning \& Growth Perspective

Kaplan and Norton's findings determined that successful companies define their objectives from the four perspectives of aims and select measures for evaluation, they designate lower aims from these measures during evaluative period, then they plan and fulfill administrative proceedings and innovations for achievement of these aims. Kaplan and Norton called this method of performance evaluation as a method of balance or balanced scorecard. (Kaplan \& Norton 2004, p12-16)

Balanced scorecard completes the financial indexes of last performances with the determiner indexes of future performances. Aims and indexes of balanced scorecard are determined by strategy and perspective of organization. These aims and indexes look at performance of organization in four aspects: financial, customer, internal process and growth and learning.

As it is shown in Figure 1, these four perspectives provide a frame for balanced scorecard (Kaplan \& Norton, 1996).

$<$ Figure 1 about here $>$

Perspective and strategy:

Financial perspective: in order to achieve financial success, how should we encounter shareholders?

Customer perspective: in order to achieve our aims, how should we behave with customers?

Internal processes perspective: what commercial processes are necessary in order to satisfy shareholders and customers? Growth and learning perspective: how do we promote individuals' abilities in order to achieve perspective?

Financial perspective

In Financial perspective of balanced scorecard, economical results of utilizing strategies are evaluated. As financial operation can be evaluated with indexes like operational interest, capital return and surplus value rate in systems of planning, before strategic planning and control systems, it can be evaluated in balanced scorecard as an operation for performance evaluation and an instrument for controlling as well as financial performance with similar indexes and relations (Robert \& Simons, 2000).

\section{Customer perspective}

In customer perspective of balanced scorecard, managers firstly designate customer and market's parts trending to compete. Designated parts will include customers as well as present and potential markets. This perspective balanced scorecard involves several public indexes and a series of secondary indexes. Essential indexes consist of customer satisfaction, customer preservation, attraction of new customer, profit per customer, market share in customer and market's parts (Kaplan and Norton, 1996).

\section{Learning and growth perspective}

Learning and growth of organization derives from three principle sources of humanitarian power, information systems, instructions and organizational processes. Level of achievement to capabilities and special power are evaluated in these sources of learning and growth perspective of balanced scorecard.

In order to evaluate aims related to this perspective, factors like achievement rate of customer to information and internal processes by managers and operational employees are evaluated regarding information systems and coextensive rate of employees' motivations with goal of organization about instructions and organizational procedures (Robert \& Simons, 2000). 


\section{Internal processes perspective}

In internal processes perspective of balanced scorecard, managers firstly designate key internal processes that should be emphasized due to fulfill strategy on them (these process enable the organization to value for the customer attraction and preservation and to provide shareholders' expectations) (Robert \& Simons,

Every business involves a collection of special processes in order to put a value on customer and financial results for shareholders. Procedure of balanced scorecard selects the concatenate model of Porter value as a public pattern for using in perspective of internal processes which include three processes of innovation, operation and after-sales service (Kaplan \& Notron, 1996).

\section{Fuzzy Logic}

\subsection{Fuzzy numbers and verbal variables}

Theory of Fuzzy collections are formally presented for the fist time in an article published in information and control magazine in 1969 by Professor Lotfi Asgarzadeh, Iranian scientist and professor of California University in Berkley. From that time till now, it has been improved and meditated very much and has had various applications in different fields. Fuzzy collection is the generalization of a classic collection that allows to generalization every amount in $[1,0]$, whereas a classic collection can only have [0,1]. Theory of Fuzzy collections make possible for planning and mathematic operations in the sphere of Fuzzy numbers (Cengiz, 2003).

\subsection{Triangular fuzzy numbers}

Calculation with Fuzzy numbers due to their special structure is very complex and need long time. In order to facilitate and make functional the fuzzy numbers, special fuzzy numbers are used in calculation. In this research, the triangular fuzzy numbers are utilized. A triangular fuzzy number can be demonstrated with a regular triad of $(l, m, u)$ that $l$ and $u$ are the lower and upper and $m$ is middle amount; $x$ is between $l$ and $u$.

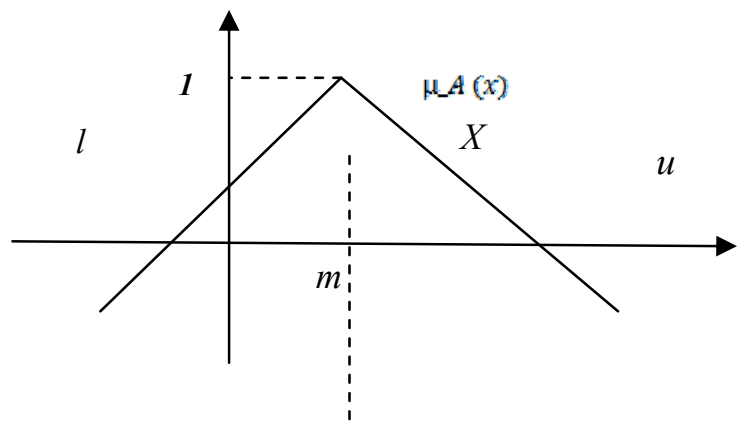

\subsection{Verbal variable}

Verbal variable is a variable that its quantity is defined according to verbal terms. Concept of verbal variable in encounter with positions is complex; and very useful in the situation which can not be nicely defined. For example, weight is a verbal variable that includes amounts like very little, little, medium, much and very much. Fuzzy numbers show verbal variables.

Whereas comparisons between utilized criterions are qualitative and can not been indicated as a number, fuzzy data is used in order to turn qualitative criterions to quantitative criterions and find proportional numbers.

$<$ Figure 2 about here $>$

Steps of Calculating weight indexes with the method of dual comparisons Matrix (method of Yoong-Chang)

1. Creating levels of criterions: the first step in calculating weight of indexes is to create graphical presentation being as levels of problems indexes in which aim, criterions, factors and sub factors are represented.

2. Creating dual comparison matrixes: in this step, a matrix of judgment is created in order to achieve weights being related to elements of every level for every criterion's levels, factors and sub factors.

3. Calculating incompatibility rate of dual judgment matrixes: compatibility of matrix represents how much a person is incompatible in dual comparisons; in other words, it presets credit rate of decision maker. According to Saati statement, rate of incompatibility of a matrix should not be more than $1 \%$, otherwise it is better to revise in judgments.

4. Calculating numbers of combinative degree of matrix: if we have exponent of T and $a_{i j}^{t}=\left[l_{i j}^{t}, m_{i j}^{t}, u_{i j}^{t}\right]$, T would be the specialized triangular number, a geometric mean is combined. After combining theories in a matrix, every level of 
valuable dual matrix under $\mathrm{Sj}$ being a triangular fuzzy number is calculated as following equation:

$$
S_{j}=\sum_{j=1}^{m} M_{g i}^{j} \otimes\left(\sum_{i=1}^{n} \sum_{j=1}^{m} M_{g i}^{j}\right)^{-1}
$$

Rate of $\sum_{j=1}^{m} M_{g i}^{j}$ being addition of fuzzy number in every level is achieved by additive operations of fuzzy:

$$
\sum_{j=1}^{m} M_{g i}^{j}=\left(\sum_{j=1}^{m} l_{j}, \sum_{j=1}^{m} m_{j}, \sum_{j=1}^{m} u_{j}\right)
$$

And then:

$$
\left(\sum_{i=1}^{n} \sum_{j=1}^{m} M_{g i}^{j}\right)^{-1}=\left(\frac{1}{\sum_{i=1}^{n} u_{i}}, \frac{1}{\sum_{i=1}^{n} m_{i}}, \frac{1}{\sum_{i=1}^{n} l_{i}}\right)
$$

5. if $M_{1}$ and $M_{2}$ show two triangular fuzzy numbers, possible degree of bigness for $M_{2} \quad$ and $M_{1}$ is defined as following equation:

$$
V\left(M_{2} \geq M_{1}\right)=\sup _{y \geq x}\left\lfloor\min \left(\mu_{m_{1}}(x), \mu_{m_{2}}(x)\right)\right\rfloor
$$

And also can be calculated as following formula:

$$
V\left(M_{2} \geq M_{1}\right)=\operatorname{hgt}\left(M_{2} \cap M_{1}\right)=\mu_{M_{2}}(d)=\left\{\begin{array}{cc}
\text { if } m_{2} \geq m_{1} \\
1 & \text { if } l_{1} \geq u_{2} \\
0 & \text { otherwise } \\
\frac{l_{1}-u_{1}}{\left(m_{2}-u_{2}\right)-\left(m_{1}-l_{1}\right)} &
\end{array}\right.
$$

In above formula, (d) is the highest common point between $\mu_{m_{1}}$ and $\mu_{m_{2}}$.in order to compare $M_{1}$ and $M_{2}$, we needed

$$
\begin{aligned}
& V\left(M_{1} \geq M_{2}\right) \quad \text { and } V\left(M_{2} \geq M_{1}\right) . \\
& \quad V\left(M \geq M_{1}, M_{2}, \ldots, M_{k}\right)=\left[V\left(M \geq M_{1}\right) \text { and } V\left(M \geq M_{2}\right) \text { and } \ldots \text { and } V\left(M \geq M_{k}\right)\right] \\
& \quad=\min V\left(M \geq M_{i}\right), i=1,2,3, \ldots, k
\end{aligned}
$$

6. Possible Degree of bigness: in order that a gibbous fuzzy number of $(\mathrm{k})$ be bigger than a gibbous fuzzy number, do the following formula:

$$
\begin{aligned}
& V\left(M \geq M_{1}, M_{2}, \ldots, M_{k}\right)=\left[V\left(M \geq M_{1}\right) \text { and } V\left(M \geq M_{2}\right) \text { and } \ldots \text { and } V\left(M \geq M_{k}\right)\right] \\
& =\min V\left(M \geq M_{i}\right), i=1,2,3, \ldots, k
\end{aligned}
$$

Suppose $d^{\prime}\left(A_{i}\right)=\min V\left(S_{i} \geq S_{k}\right)$, if we have $k=1,2, \ldots, n ; k \neq i$. vector of weight will be as following method:

$$
w^{\prime}=\left(d^{\prime}\left(A_{1}\right), d^{\prime}\left(A_{2}\right), \ldots, d^{\prime}\left(A_{n}\right)\right)^{T}, i=1,2, \ldots, n
$$




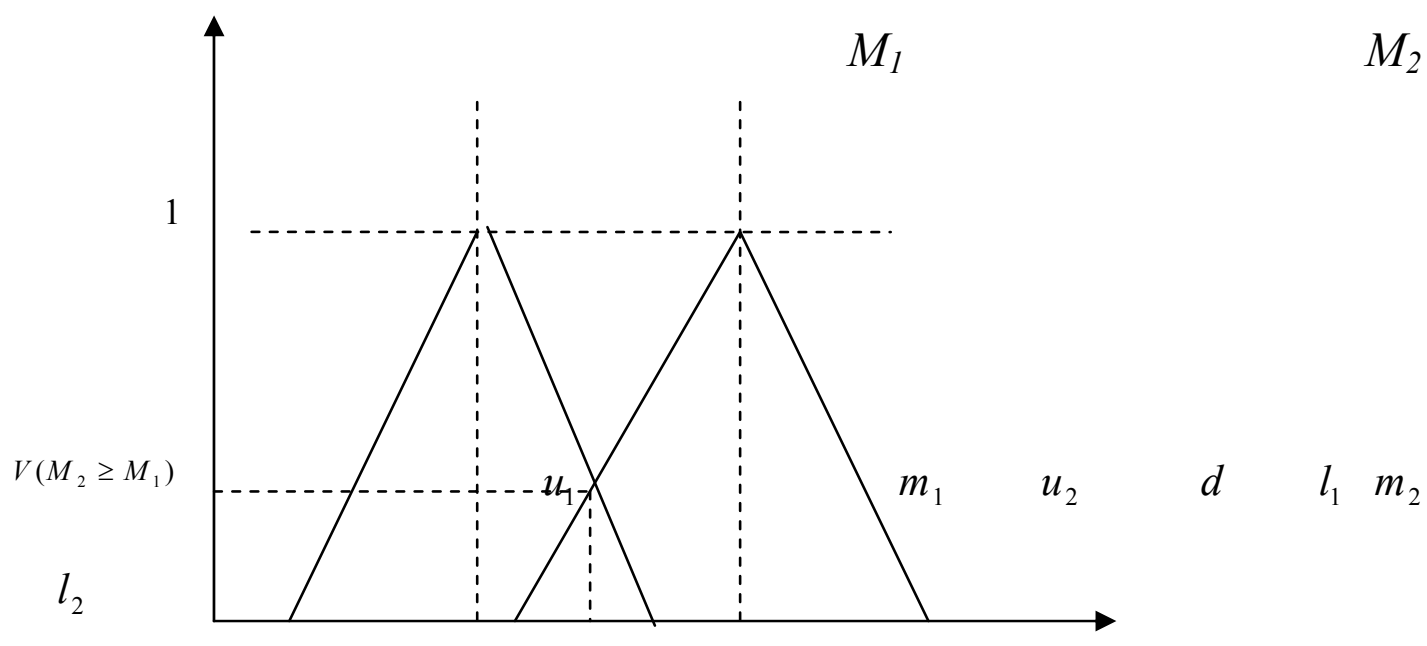

Common between $M_{1}$ and $M_{2}$

7. Through normalizing the resultant vector, vector normalized weight will be achieved. In order to normalize, every number is divided on the sum of vector numbers in which the following vector is achieved:

$$
w=\left(d\left(A_{1}\right), d\left(A_{2}\right), \ldots, d\left(A_{n}\right)\right)^{T}
$$

And in this case, ${ }^{W}$ is unfuzzy number (Kahraman, 2003).

\section{Explanation of TOPSIS, VIKOR and SAW methods}

\subsection{Method of TOPSIS}

Method of TOPSIS (Technique for Order Preference by Similarity to Ideal Solution) is suggested by Hwang \& Yoon in 1981. This model is one of the best models of multi-criteria decision making and it can be used so much. In this method, $\mathrm{m}$ is evaluated by $\mathrm{n}$ criteria.

This technique is based on the concept that selective alternative should have the nearest distance with ideal positive solution (best possible manner) and farthest distance with ideal negative solution (worst possible manner). It is supposed that popularity of every index is regularly increasing or decreasing (Husseini, 2002).

TOPSIS operations are as following steps:

Step one: matrix forms decision making and is normalized by non-scaling methods

$$
r_{i j}=\frac{x_{i j}}{\sqrt{\sum_{i=1}^{m} x_{i j} \wedge 2}}
$$

Step two: Matrix is calculated by normal weighty decision making. Value of normal weight of vij is calculated as following formula:

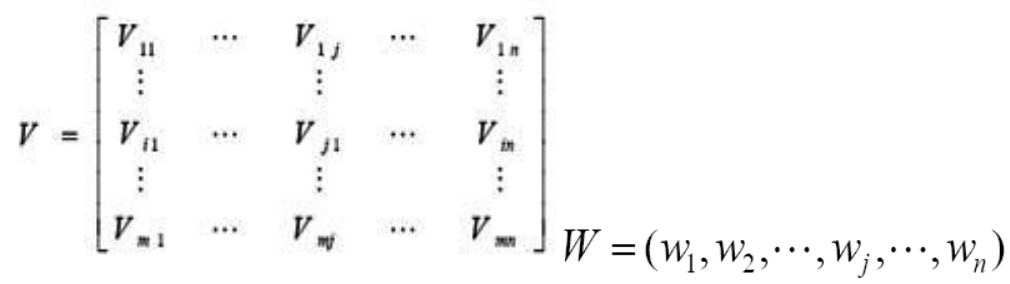

While wj is the square of character of criterion and algebraic addition of weights is 1 . 
Step three: ideal solution of positive and negative is determined:

$$
\begin{aligned}
& A^{+}=\left\{\left(\max _{i} v_{i j} \mid j \in J\right),\left(\min v_{i j} \mid j \in J^{\prime}\right) \mid i=1,2, \ldots, m\right\}=\left\{v_{1}^{+}, v_{2}^{+}, \ldots, v_{n}^{+}\right\} \\
& A^{-}=\left\{\left(\min _{i} v_{i j} \mid j \in J\right),\left(\max v_{i j} \mid j \in J^{\prime}\right) \mid i=1,2, \ldots, m\right\}=\left\{v_{1}^{-}, v_{2}^{-}, \ldots, v_{n}^{-}\right\}
\end{aligned}
$$

a + is depended on profit index and a- is depended on expenditure's index

Step four: calculation of separation measures.

Distance of every ideal solution is as following equation:

$$
S_{i}^{+}=\sqrt{\sum_{j=1}^{n}\left(v_{i j}-v_{j}^{+}\right)^{2}}
$$

Also, distance of negative solution is as following:

$$
S_{i}^{-}=\sqrt{\sum_{j=1}^{n}\left(v_{i j}-v_{j}^{-}\right)^{2}}
$$

Step five: comparative- nearness calculation of ideal solution. Comparative nearness of $\mathrm{a}_{\mathrm{j}}$ is defined as following:

$$
C_{i}=\frac{S_{i}^{-}}{S_{i}^{+}+S_{i}^{-}}
$$

Step six: hierarchy of precedence application

In this alternative, if the rate of ci be more, higher rank will achieve in comparison with other alternatives.

\subsection{Method of VIKOR}

Method of VIKOR is one of multi-criterions solutions. In problems of disproportionate criterions, decision maker needs a solution being near to ideal solution and all alternatives are evaluated in accordance with criterions in a situation that decision maker is not able to designate and state preponderances of a problem at the beginning and planning.

This method can be defined as an effective instrument for making decision. This method has been used by Tzeng and Opricovic in some parts like engineering of earthquake and environment (Tzeng \& Opricovic, 2002). If there would be a problem of making decision of multi-criterions, $\mathrm{m}$ will be criterion and $\mathrm{n}$ will be alternative. In order to select best alternative in this method, use following steps (Tzeng \& Opricovic, 2002):

1. Constituting matrix of decision making:

Concerning numbers of criterions, alternatives and evaluation of all alternatives for different criterions, matrix of decision making is formed by following formula:

$$
D=\left[\begin{array}{ccc}
X_{11} & \cdots & X_{n} \\
\vdots & \cdots & \cdots \\
X_{m !} & \cdots & X_{m+r}
\end{array}\right]
$$

$\mathrm{W}=[\mathrm{w} 1, \mathrm{w} 2, \ldots, \mathrm{wn}]$

$\mathrm{xij}$ is the performance of $\mathrm{jm}(\mathrm{j}=1,2, \ldots, \mathrm{n})$ in relationship with criterion of $\mathrm{mi}(\mathrm{j}=1,2, \ldots, \mathrm{n})$

2. Determining weighting matrix of criterions:

In this step in terms of the importance of different criterions in making decision, matrix is defined as following equation:

$\mathrm{W}=[\mathrm{w} 1, \mathrm{w} 2, \ldots, \mathrm{wn}]$

3. Determining the best and worst rate from the existent rates for every criterion in decision making matrix:

The best and worst rates for positive and negative criterions are calculated as following formula:

$<$ Table 1 about here>

4. Calculating ratings of $s$ and $r$ 
Ratings of $\mathrm{s}$ and $\mathrm{r}$ are calculated in accordance with 6 and 7 relationship. $\mathrm{w}_{\mathrm{i}}$ is concerned as weighty rating for criterion.

$$
\begin{gathered}
S_{i}=\sum_{i=1}^{n} w_{i} \frac{\left(f_{i}^{*}-f_{i j}\right)}{\left(f_{i}^{*}-f_{i}^{-}\right)} \\
R_{i}=\max \left[w_{i} \frac{\left(f_{i}^{*}-f_{i j}\right)}{\left(f_{i}^{*}-f_{i}^{-}\right)}\right]
\end{gathered}
$$

5. Calculating q:

Q: is calculated in accordance with number 8 relationship.

$$
\begin{gathered}
Q_{i}=v \frac{\left(S_{j}-S^{*}\right)}{\left(S^{-}-S^{*}\right)}+(1-v) \frac{\left(R_{j}-R^{*}\right)}{\left(R^{-}-R^{*}\right)} \\
R^{*}=\min _{\mathrm{j}} \mathrm{R}_{\mathrm{j}}, \quad R^{-}=\max _{\mathrm{j}} \mathrm{R}_{\mathrm{j}}, \quad S^{*}=\min _{\mathrm{j}} \mathrm{S}_{\mathrm{j}}, \quad S^{-}=\max _{\mathrm{j}} \mathrm{S}_{\mathrm{j}}
\end{gathered}
$$

Parameter of $\mathrm{V}$ is selected in accordance with agreement degree of decision makers group, if there would be high agreement it will be more than $75 \%$, if there would be most voters' agreement it will be $5 \%$ and there would be lower agreement it will be lower than $5 \%$.

6. Ranking alternatives on the basis of ratings' reduction of $\mathrm{r}, \mathrm{s}$ and $\mathrm{q}$

7. In this step, concerning $\mathrm{s}$ and $\mathrm{q}$ ratings, alternatives are ranked in three groups and finally an alternative is selected as better one that is designated as the better alternative in all three groups. Arrangement of setting alternatives is concerned in terms of reduction of ratings': $r$, s and q. it should be said that in group of $q$, an alternative is selected as the better one which satisfies the following two requirements:

$$
Q\left(A^{(2)}\right)-Q\left(A^{(1)}\right) \geq \frac{1}{n-1}
$$

A. First requirement: $A(1)$ and $A(2)$ demonstrate regularly the first and second better alternatives in group of $q$ and $n$, following relationship is:

$$
Q\left(A^{(2)}\right)-Q\left(A^{(1)}\right) \geq \frac{1}{n-1}
$$

B: Second requirement: alternative of a(1) should be designated as better rank in one of $\mathrm{r}$ and $\mathrm{s}$ groups.

While the first requirement would not be existed, a collection of alternatives is selected as the better alternatives as following formula

Better alternative $=\mathrm{A}(1), \mathrm{A}(2), \ldots \mathrm{A}(\mathrm{M})$

The highest rating of $\mathrm{m}$ is calculated as following formula:

$$
Q\left(A^{(M)}\right)-Q\left(A^{(1)}\right)<\frac{1}{n-1}
$$

While the second requirement would not be existed, two alternatives of $\mathrm{A}(1), \mathrm{A}(2)$ are selected as the better alternatives.

\subsection{Method of $S A W$}

Method of SAW (Simple Additive Weighting Method) is one of the oldest methods being used in MADM. As with assumption of $\mathrm{w}$ (weight is important in indexes) for it, the best alternative ( $\mathrm{a}^{*}$ ) is calculated as following formula:

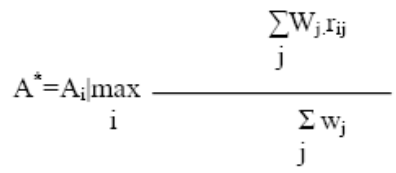

And if it would be $\sum \mathrm{w}_{\mathrm{j}}=1$, we have: 


\section{$\mathrm{A}^{*}=\left\{\mathrm{A}_{\mathrm{i}} \mid \max \sum_{\mathrm{j}} \mathrm{w}_{\mathrm{j}} . \mathrm{r}_{\mathrm{ij}}\right\}$}

\subsection{Method of Borda}

It is one of consolidating methods which is based on the rule of majority. When several methods are used due to rank alternatives, method of Borda can be used to consolidate resultant results. Way of working in Borda is that while im is preferred on jm in most methods, this case is shown with $\mathrm{m}$ in dual comparisons; also if there would not be vote of majority in dual comparison or there would be similar vote, it is coded with $\mathrm{x}$. primary criterion in this method is that Bordars of alternative are with the majority in several times in every line (Momeni, 2008).

\section{Research Methodology and Design}

Principally, research is a systematic process that always begins with planning issue or question which its aim is to answer the propounded issues in scientific method. In respect to research's aim, it is as practical studies because these examined theoretical studies have firstly analyzed to recognize and solve problems statistically and then they have paid attention to recognition and evaluation of effective factors on behaviors of managers and decision makers and it has slightly considered reasons of manifestation. Practical studies emphasize chiefly on the most affecting functions and consider slightly reasons of factors.

This article is a descriptive research (not experimental). It means that its aim is to describe situation or phenomena of the evaluative case. It should be said that the descriptive research is implemented for more recognition of present situation or help decision making process.

Managers of different parts of adopted private banks in bourse and technical experts of information in statistical banking industry constitute this research. Whereas volume of society is low and all individuals of the society are experts and specialists, hence all of them are selected as the statistical sample. Two methods of library and field are used due to collect data in this article. In order to review literature, method of library and reference to libraries, scientific magazines, and different scientific bases on internet network are used. But principle information of research is collected through field method and distribution of questionnaires as well as interview with superior managers and related experts.

\subsection{Introducing the model and its components}

Step 1: determination of indexes of every group concerning business identity

Through studying perspectives and missions of banks of Parsian, Eghtesad Novin and Kar-Afarin, it is distinguished that all three banks follow similar major perspectives and aims, but their functions are different in achievement of this aim. Strategic plan of banks is represented in table 2 .

$<$ Table 2 about here $>$

After reviewing literature of research, principal indexes were educed for evaluating banks in four perspectives in model of balanced scorecard and rendered experts in the field of banking in order to represent their suggestions about these indexes. After collecting experts' suggestions and ideas, 16 principal indexes being proportional to this field were achieved for evaluation of banks. Indeed, in function, for evaluation of banks, 13 principal indexes have been used due to lack of necessary data in this field which have been shown in table 2 .

From these indexes, 4 indexes to customer perspective, 3 indexes to internal process of perspective, 4 indexes to financial perspective and 2 indexes to growth and learning perspective are related. The indexes that are put away in this research due to lack of data are indexes of availability to information and regulating affairs being in perspective of growth and learning as well as index of customer's loyalty. Through recognizing principle indexes in four perspectives, BSC was used in order to precise evaluation of banks in the way of Delphi and determining secondary indexes being proportional to principal indexes. Subsequent to final collection, 86 secondary indexes were recognized for evaluating banks that were presented in tables 3 to 6 .

Step 2: constitution of dual comparisons of matrix and determination of effective criterions in evaluation of banks performance are to assess comparative importance of effective criterions in evaluation of banks. Also, questionnaires \{evaluating comparative importance of effective criterions in evaluation of banks performance\} were provided and distributed among experts, then they were collected and incompatibility of decision making matrixes was calculated. Whereas the comparisons between used criterions were qualitative and were not stated as a number, they were presented as the verbal terms like, very much, much, middle, a little and very a little.

In this step, due to convert qualitative criterions to quantitative criterions and find appropriate numbers with concerned terms, fuzzy numbers were used. Then dual comparisons matrixes were converted to decision making matrixes by geometric mean (combined matrixes of dual comparisons) and weight of criterions were recognized by method of Chang.

Step 3: constitution of decision making matrixes and evaluation of banks with method of MADM

After recognizing weight of criterions, decision making matrix was constituted through gathering related data with every 
criterion in order that possibility of evaluation of banks performance were utilized by techniques of TOPSIS, VIKOR and SAW. Decision making matrix was represented in every size of balanced scorecard along with weight of every perspective, index and sub index in tables 3-6.

$<$ Table 3 to Table 6 about here $>$

Step 4: whereas it was possible that results of ranking would be different in every method, so method of Borda has been used in final ranking being one of combination methods.

\section{Ranking of Banks by TOPSIS, VIKOR and SAW Methods}

\subsection{Method of TOPSIS}

This technique is based on the selected alternative that should have the nearest distance with positive ideal resolution (best resolution) and farthest distance with the negative ideal resolution (worst resolution). Decision making matrix was firstly constituted by methods of normalized non-measuring methods and then was calculated by normal weight. Final result of TOPSIS is represented in table 7.

$<$ Table 7 about here $>$

\subsection{Method of $S A W$}

Resultant ranking of SAW technique is as following:

$<$ Table 8 about here $>$

\subsection{Method of VIKOR}

After constitution of decision making matrix, the best and worst ranking from the current ratings for every criterions in decision making was determined and then ratings of $\mathrm{s}, \mathrm{r}$ and $\mathrm{q}$ were calculated.

- Achieved solution of minj sj has the maximum of collaborative desirability (on the basis of majority rule), it can be said that this solution provides comparative satisfaction of majority criterions, from nearness to ideal.

- Achieve solution of minj rj has the lowest rate of the most matters for every criterions from the lack of selecting ideal or nearness to anti-ideal. (it is similar to minmas and it is conservative).

- Coefficient of $v$ has been introduced as the strategic weight of decision making of majority criterions or maximum of collaborative desirability; here, it is considered $75 \%$

Alternatives on the basis of $r, s$ and $q$ are ranked reductionaly that brought about ranking in three lists. Alternative of a is suggested as a agreeable solution concerning $\mathrm{q}$ and following two requirements is ranked as the best case.

$$
\mathrm{Q}\left(\mathrm{a}^{\prime \prime}\right)-\mathrm{Q}\left(\mathrm{a}^{\prime}\right)>=\mathrm{DQ}
$$

Alternative of "a is ranked in the list of $\mathrm{q}, \mathrm{dq}=1 /(\mathrm{j}-1)$ and $\mathrm{j}$ is the number of alternatives.

Second requirements: acceptable stability in decision making.

Alternative of a has the highest rank in the list of ranking $\mathrm{s}$ or $\mathrm{r}$. such agree solution in the process of decision making remains stable. If one of two requirements doesn't fulfill, a collection of agreeable solution is represented.

While the first requirement doesn't exist, a collection of alternatives is selected like the following formula as the best alternatives.

Hyper alternatives $=\mathrm{A}(1), \mathrm{A}(2) \ldots \ldots, \mathrm{A}(\mathrm{M})$

Maximal rate of $\mathrm{m}$ is calculated as following equation:

$$
Q\left(A^{(M)}\right)-Q\left(A^{(1)}\right)<\frac{1}{n-1}
$$

While the second requirement would not be existed, both alternatives are concerned as the best alternative.

As it is said, final ranking of banks by the method of VIKOR is that Parsiyan and Eghtesad Novin are in the first rank and Kar-Afarin is in the last rank.

Calculation of $\mathrm{s}, \mathrm{r}$ and $\mathrm{q}$ is represented in table 9 .

\section{$<$ Table 9 about here $>$}

\subsection{Final ranking by method of Borda}

Borda is one of consolidation method that is based on majority rule. In this research, the achieved rankings are consolidated by three methods of TOPSIS, SAW and VIKOR that its results are represented in table 10.

$\mathrm{M}$ means that line foregoes column and $\mathrm{x}$ shows that column forgoes line.

$$
<\text { Table } 10 \text { about here }>
$$

\section{Conclusion and suggestions}


In this research, criterions and sub-criterions of banks evaluation were distinguished in four perspectives of BSC and weight of criterions and sub-criterions were determined by experts. Hence this model is able to evaluate other private banks. One of important functions of represented model in this article is evaluation and comparison of governmental banks privatizing with private banks so that governmental banks can recognize their status and utilize their politics in the field of competition with private banks

In order to use this model for the evaluation of different organizations' performance, quantitative and qualitative indexes in every organization were firstly distinguished by relative characters of principle indexes of balanced scorecard and then weight of indexes was determined by dual comparisons matrixes. This model is able to include relative indexes with the model of balanced evaluation. So, it can be used for evaluation of different organizations. It is necessary to say that indexes of every organization can be distinguished in terms of field research and review in literature of research.

\section{References}

Andersen, B., Henriksen, B., and Aarseth,W. (2006). Professional practice holistic performance management: an integrated framework. International Journal Productivity and Performance Management. Vol. 55, No.1, pp.61-78. doi:10.1108/17410400610635507, http://dx.doi.org/10.1108/17410400610635507

Arshadi, N., \& Lawrence, E. C. (1987). An empirical investigation of new bank performance. Journal of Banking and Finance, 11(1), 33-48.

Asgharpoor, M.J. (1998), Multi Criterion Decision Making, Tehran University, $1^{\text {st }}$ edition.

Azar, A., and Rajab Zadeh, A. (2002), Practical decision Making, Negah Danesh, $1^{\text {st }}$ edition.

Bellman, R. E., \& Zadeh, L. A. (1970). Decision-making in a fuzzy environment. Management Science, 17(4), 141-164.

Bernard, W., Guo, L., Li, W., \& Yang, D. (2006). Reducing conflict in balanced scorecard evaluations. Organizations and Society.

Buckley, J. J. (1985). Fuzzy hierarchical analysis. Fuzzy Sets and Systems, 17(3), 233-247.

doi:10.1016/0165-0114(85)90090-9, http://dx.doi.org/10.1016/0165-0114(85)90090-9

Busi, M., and Bititci, U.(2006). Collaborative performance management: present gaps and future research. Collaborative Performance Management. Vol. 55 No.1.

Collier, D. A. (1995). Modeling the relationships between process quality errors and overall service process performance. International Journal of Service Industry Management, 6(4), 4-19. doi:10.1108/09564239510096876, http://dx.doi.org/10.1108/09564239510096876

Frigo, M. L., Pustorino, P. G., \& Krull, G. W. (2000). The balanced scorecard for community banks: translating strategy into action. Bank Accounting and Finance, 13(3), 17-29.

Hwang, C. L., \& Yoon, K. (1981). Multiple attribute decision making methods and applications. New York: Springer-Verlag.

Kaplan, and Norton. (2005), Robert S. and David P., plan of strategy, translated by Hussein Akbari and Masood Soltani and Amir Maleki, Cultural-artist Group of Aryana.

Kloot, L. \& John, M. (2000). Strategic performance management: a balanced approach to performance management issues in local government. Management Accounting Research, 11, pp 231-251.

Kravchuk, R., \& Ronald w, S. (1996). Designing effective performance measurement systems under the government performance and results act of 1993. Public Administration Review, vol. 56.

Lee, A. H. I., Chen, W. C., \& Chang, C. J. (2008). A fuzzy AHP and BSC approach for evaluating performance of it department in the manufacturing industry in Taiwan. Expert Systems with Applications, 34(1), 96-107. doi:10.1016/j.eswa.2006.08.022, http://dx.doi.org/10.1016/j.eswa.2006.08.022

Lee, A. H., Chen, W., and Chang, C. (2006). A fuzzy AHP and BSC approach for evaluating industry in Taiwan. Expert systems with applications.

Mehragan, M. R., Shahbandarzadeh, H. (2005) . Representing a method for performance evaluation of banks branches by the technique of multi-indexes decision making. Financial Researches Quarterly.

Meyer, D. W., \& Markiewicz, M. K. (1997). Developing a balanced scorecard at Wachovia Corporation. Bank Accounting and Finance, 11(1), 13-19.

Momeni, Mansoor (2006), modern discussion about operational research, $1^{\text {st }}$ edition, Tehran, Management College of Tehran University.

Norton, D. P., Contrada, M. G., \& Lofrumento, T. (1997). Case study: how chase Manhattan bank uses the balanced scorecard. Banking Accounting and Finance, 11(1), 3-11.

Opricovic, S., \& Tzeng, G. H. (2003). Defuzzification within a fuzzy multicriteria decision model. International journal of uncertainty, Fuzziness and Knowledge-based Systems, 11(5), 635-652. 
Opricovic, S., \& Tzeng, G. H. (2007). Extended VIKOR method in comparison with outranking methods. European Journal of Operational Research, 178(2), 514-529.

Phuong, H., \& Yin, K. (2000). Study of bank selection decisions in Singapore using the analytical hierarchy process. International Journal of Bank Marketing, 18:3,170-180.

Robert, S., Kaplan, and Norton, D. (1996). 'Translating strategy into action 'the balanced scorecard'. Harvard Business s.p.

Schaffnit, D., Rosen, J., \& Paradi, C. (1997). Best practice analysis of bank branches: an application of DEA in a large Canadian bank. European Journal of Operational Research, 98, 269-289.

Simons, R. (2000). Performance measurement \& control systems for implementing strategy, Prentice Hall.

Wang, T. C., \& Chang, T. H. (2007). Application of TOPSIS in evaluating initial training aircraft under a fuzzy environment. Expert Systems with Applications, 33(4), 870-880. doi:10.1016/j.eswa.2006.07.003, http://dx.doi.org/10.1016/j.eswa.2006.07.003

Wua, H., Tzeng, G., Chen, Y. (2009). A fuzzy MCDM approach for evaluating banking performance based on balanced scorecard. Journal homepage: www.elsevier.com.

Yeo, R. (2003). The tangibles and intangibles of organizational performance. Team Performance Management. Volume 9. Number 778. pp 199-204. doi:10.1108/13527590310507453, http://dx.doi.org/10.1108/13527590310507453

Zadeh, L. A. (1965). Fuzzy sets. Information and Control, 8(3), 338-353. doi:10.1016/S0019-9958(65)90241-X, http://dx.doi.org/10.1016/S0019-9958(65)90241-X

Zeleny, M. (1982). Multiple criteria decision making. New York: McGraw-Hill.

Table 1. The best and worst amount for positive and negative criterions

\begin{tabular}{|c|c|c|}
\hline Type of criterion & best & worst \\
\hline Positive criterion & $\mathrm{F}_{\mathrm{i}}{ }^{*}=\operatorname{max~} \mathrm{f}_{\mathrm{ij}}$ & $\mathrm{F}_{\mathrm{i}}{ }^{-}=\min \mathrm{f}_{\mathrm{ij}}$ \\
\hline Negative criterion & $\mathrm{F}_{\mathrm{i}}{ }^{*}=\min \mathrm{f}_{\mathrm{ij}}$ & $\mathrm{F}_{\mathrm{i}}{ }^{-}=\max \mathrm{f}_{\mathrm{ij}}$ \\
\hline
\end{tabular}

$\mathrm{fi}^{*}$ is the best rating of criterion among all alternatives.

Table 2. Strategic plan of bank in BSC model

\begin{tabular}{|c|l|}
\hline Perspective & \multicolumn{1}{|c|}{ Strategic aims } \\
\hline Financial & $\begin{array}{l}\text { Increase in benefits, Profitability, shareholders' efficiency and optimal } \\
\text { management of costs and incomes. }\end{array}$ \\
\hline Customer & $\begin{array}{l}\text { keep and expand market's share and provide services and production with } \\
\text { various quality and competitive prices to the customers, active presence in } \\
\text { currency, internal and external financial markets of the country and expand } \\
\text { and provide foreign exchange services and products }\end{array}$ \\
\hline Internal process & $\begin{array}{l}\text { Expand extended sphere of modern banking services, electronic banking, } \\
\text { processes related to services, recognition of requirements and ranking } \\
\text { customers }\end{array}$ \\
\hline $\begin{array}{c}\text { Employees' growth and } \\
\text { learning }\end{array}$ & $\begin{array}{l}\text { Improve employees' efficiency in effectiveness educations, coextend aims } \\
\text { and employees' benefits with shareholders and turn bank to a learning } \\
\text { organization }\end{array}$ \\
\hline
\end{tabular}


Table 3. Decision making matrix in internal processes

\begin{tabular}{|c|c|c|c|c|c|c|}
\hline Concept & Factors & Variables & Weight & Parsiyan & $\begin{array}{r}\text { Eghtesad } \\
\text { Novin }\end{array}$ & KarAfrin \\
\hline \multirow{20}{*}{$\begin{array}{c}\text { Perspective } \\
\text { of } \\
\text { Internal } \\
\text { Processes }\end{array}$} & \multirow{7}{*}{$\begin{array}{l}\text { Production } \\
(0.289)\end{array}$} & $\begin{array}{c}\text { Rate of income of bank } \\
\text { given facilities (billion } \\
\text { Riyal) }\end{array}$ & $\% 257$ & 27853 & 13924 & 8.4379 \\
\hline & & Volume of total discounts & $\% 212$ & 161609 & 87381 & 30493 \\
\hline & & $\begin{array}{l}\text { Rate of bank investments } \\
\text { (billion Riyal) }\end{array}$ & $\% 158$ & 5084.7 & 1427.8 & 2502 \\
\hline & & $\begin{array}{l}\text { Rate of income resulting } \\
\text { from bank investments } \\
\text { (billion Riyal) }\end{array}$ & $\% 093$ & 712.4 & 401.6 & 469.8 \\
\hline & & $\begin{array}{c}\text { Rate of income in } \\
\text { banking commission (billion } \\
\text { Riyal) }\end{array}$ & $\% 110$ & 627 & 571.6 & 400.4 \\
\hline & & $\begin{array}{c}\text { Other operational } \\
\text { incomes of bank (billion } \\
\text { Riyal) }\end{array}$ & $\% 074$ & 183.6 & 539 & 86.4 \\
\hline & & $\begin{array}{c}\text { Mean of attracted } \\
\text { discounts of every branch } \\
\text { (billion Riyal) }\end{array}$ & $\% 096$ & 928 & 436.9 & 423.5 \\
\hline & \multirow{6}{*}{$\begin{array}{l}\text { Expansion } \\
\text { of } \\
\text { Production } \\
(0.444)\end{array}$} & $\begin{array}{l}\text { Rate of discount growth } \\
\text { (percentage) }\end{array}$ & $\% 323$ & 19.9 & 40 & 31 \\
\hline & & $\begin{array}{l}\text { Rate of growth in given } \\
\text { facilities (percentage) }\end{array}$ & $\% 240$ & 20.7 & 15 & 27 \\
\hline & & $\begin{array}{l}\text { Rate of growth in bank } \\
\text { cards (percentage) }\end{array}$ & $\% 137$ & 91 & 12 & 124 \\
\hline & & $\begin{array}{l}\text { Rate of annual growth of } \\
\text { branches }\end{array}$ & $\% 100$ & 19.7 & 12.1 & 12.5 \\
\hline & & $\begin{array}{l}\text { Rate of growth in cash } \\
\text { machines }\end{array}$ & $\% 125$ & 24.8 & 24.5 & 180 \\
\hline & & $\begin{array}{l}\text { Rate of growth in } \\
\text { storable cash machines } \\
\text { (percentage) }\end{array}$ & $\% 080$ & 68 & -14 & 0 \\
\hline & \multirow{7}{*}{$\begin{array}{l}\text { Sales } \\
\text { Services } \\
(0.267)\end{array}$} & $\begin{array}{l}\text { Volume of given } \\
\text { facilities }\end{array}$ & $\% 247$ & 56665 & 61296 & 22047 \\
\hline & & $\begin{array}{l}\text { The proportion of given } \\
\text { facilities to the total } \\
\text { discounts }\end{array}$ & $\% 142$ & 35 & 320.8 & 72 \\
\hline & & $\begin{array}{l}\text { Numbers of given } \\
\text { facilities }\end{array}$ & $\% 132$ & 25153 & 649 & 14674 \\
\hline & & $\begin{array}{l}\text { Mean of given facilities } \\
\text { of every branch }\end{array}$ & $\% 107$ & 667 & 1034 & 306.2 \\
\hline & & $\begin{array}{l}\text { Numbers of opened } \\
\text { documentary credits }\end{array}$ & $\% 108$ & 3587 & 5233 & 346 \\
\hline & & $\begin{array}{c}\text { Volume of opened } \\
\text { documentary credits (million } \\
\text { Riyal) }\end{array}$ & $\% 155$ & 1658 & & 770 \\
\hline & & Per capita bank card & $\% 109$ & 26806 & & 1284 \\
\hline
\end{tabular}


Table 4. Decision making matrix in financial perspective

\begin{tabular}{|c|c|c|c|c|c|c|}
\hline Concept & Factors & Variables & Weight & Parsiyan & $\begin{array}{l}\text { Eghtesa } \\
\text { d Novin }\end{array}$ & KarAfrin \\
\hline \multirow{27}{*}{$\begin{array}{l}\text { Financial } \\
\text { Perspective } \\
\quad(0.337)\end{array}$} & \multirow{7}{*}{$\begin{array}{l}\text { Financial } \\
\text { Data } \\
(0.145)\end{array}$} & $\begin{array}{l}\text { The total fixed tangible } \\
\text { assets (billion Riyal) }\end{array}$ & $\% 112$ & 3024 & $\begin{array}{r}3242 . \\
5\end{array}$ & 614.8 \\
\hline & & $\begin{array}{l}\text { Intangible assets (billion } \\
\text { Riyal) }\end{array}$ & $\% 095$ & 132 & $\begin{array}{r}1302 . \\
5\end{array}$ & 359.1 \\
\hline & & $\begin{array}{l}\text { Operational costs (billion } \\
\text { Riyal) }\end{array}$ & $\% 113$ & 2950 & 923.5 & 392.5 \\
\hline & & $\begin{array}{l}\text { Heaps of profits (billion } \\
\text { Riyal) }\end{array}$ & $\% 152$ & 3385.5 & $\begin{array}{r}1124 . \\
7\end{array}$ & 1136.6 \\
\hline & & $\begin{array}{l}\text { Sum total of shareholders' } \\
\text { salary (billion Riyal) }\end{array}$ & $\% 193$ & 10647 & $\begin{array}{r}4642 . \\
8\end{array}$ & 3622 \\
\hline & & The total assets of bank & $\% 187$ & 192234 & $\begin{array}{r}1000 \\
37\end{array}$ & 35249 \\
\hline & & The total debits & $\% 148$ & 179337 & 95367.5 & 31627 \\
\hline & \multirow{7}{*}{$\begin{array}{l}\text { Profitability } \\
\quad(0.354)\end{array}$} & $\begin{array}{l}\text { Mean of net profit of } \\
\text { branches (billion Riyal) }\end{array}$ & $\% 109$ & 16.62 & 10.14 & 16.9 \\
\hline & & $\begin{array}{l}\text { The proportion of } \\
\text { discounts profits to income of } \\
\text { given facilities }\end{array}$ & $\% 125$ & 80 & 75.9 & 73 \\
\hline & & Revenue of any share & $\% 133$ & 443.2 & 604 & 609 \\
\hline & & $\begin{array}{l}\text { Growth of net profit } \\
\text { (percentage) }\end{array}$ & $\% 185$ & 1.53 & 50 & 63 \\
\hline & & $\begin{array}{c}\text { Return of shareholders' } \\
\text { emolument }\end{array}$ & $\% 150$ & 35.7 & 45.16 & 33.6 \\
\hline & & Return of assets & $\% 138$ & 14.6 & 2.09 & 15.1 \\
\hline & & Net profit (billion Riyal) & $\% 160$ & 3324 & $\begin{array}{r}1534 . \\
1\end{array}$ & 1217.5 \\
\hline & \multirow{7}{*}{$\begin{array}{l}\text { Financial } \\
\text { Proportions } \\
(0.121)\end{array}$} & $\begin{array}{c}\text { The proportion of } \\
\text { operational costs to total costs }\end{array}$ & $\% 109$ & 5.2 & 6.7 & 10 \\
\hline & & $\begin{array}{l}\text { The proportion of } \\
\text { operational costs to total } \\
\text { incomes }\end{array}$ & $\% 146$ & 4.5 & 6 & 7.4 \\
\hline & & $\begin{array}{l}\text { The proportion of official } \\
\text { costs to mean of assets }\end{array}$ & $\% 126$ & 0.74 & 0.9 & 1.1 \\
\hline & & $\begin{array}{l}\text { The balanced proportion of } \\
\text { given facilities to total assets }\end{array}$ & $\% 132$ & 61.3 & 61.2 & 62.4 \\
\hline & & $\begin{array}{l}\text { The proportion of } \\
\text { sufficiency to assets } \\
\text { (percentage) }\end{array}$ & $\% 171$ & 8.64 & 9.4 & 14.7 \\
\hline & & The proportion of debits & $\% 148$ & 16.8 & 20.5 & 8.7 \\
\hline & & $\begin{array}{c}\text { The proportion of } \\
\text { possession (percentage) }\end{array}$ & $\% 168$ & 5.5 & 4.6 & 10 \\
\hline & \multirow{6}{*}{$\begin{array}{l}\text { Growth } \\
\text { of } \\
\text { Incomes } \\
0.380\end{array}$} & $\begin{array}{l}\text { The proportion of income } \\
\text { of facilities to total incomes }\end{array}$ & $\% 171$ & 94 & 91.7 & 82.3 \\
\hline & & $\begin{array}{l}\text { Share of incomes from } \\
\text { services commission }\end{array}$ & $\% 136$ & 1.2 & 3.7 & 9.1 \\
\hline & & $\begin{array}{l}\text { Annual income for every } \\
\text { person (billion Riyal) }\end{array}$ & $\% 140$ & 8 & 6.567 & 4.07 \\
\hline & & $\begin{array}{l}\text { The total incomes to mean } \\
\text { of assets }\end{array}$ & $\% 186$ & 16.6 & 15.3 & 15.1 \\
\hline & & $\begin{array}{l}\text { Growth of incomes } \\
\text { (percentage) }\end{array}$ & $\% 220$ & 27 & 56 & 46 \\
\hline & & $\begin{array}{l}\text { Annual incomes in every } \\
\text { branch (billion Riyal) }\end{array}$ & $\% 147$ & 147 & 79.4 & 73.9 \\
\hline
\end{tabular}


Table 5. Decision making matrix in customer perspective

\begin{tabular}{|c|c|c|c|c|c|c|}
\hline Concept & Factors & Variables & Weight & Parsiyan & $\begin{array}{r}\text { Eghtesad } \\
\text { Novin } \\
\end{array}$ & KarAfrin \\
\hline \multirow{26}{*}{$\begin{array}{c}\text { Customer } \\
\text { Perspective } \\
(0.338)\end{array}$} & \multirow{7}{*}{$\begin{array}{l}\text { Operational } \\
\text { Benefits } \\
(0.260)\end{array}$} & Numbers of short run deposits & $\% 128$ & 1634247 & 1207553 & 98295 \\
\hline & & Numbers of long run deposits & $\% 138$ & 671092 & 546470 & 116991 \\
\hline & & $\begin{array}{c}\text { Numbers of interest-free } \\
\text { checking and savings accounts }\end{array}$ & $\% 107$ & 653002 & 538663 & 67652 \\
\hline & & Given interest to depositors & $\% 173$ & 22376 & 10986 & 3207 \\
\hline & & Balance of short run deposits & $\% 155$ & 65824 & 48256 & 21270 \\
\hline & & Balance of long run deposits & $\% 160$ & 94213 & 75483 & 24045.6 \\
\hline & & $\begin{array}{c}\text { Balance of interest-free } \\
\text { checking and savings deposits }\end{array}$ & $\% 139$ & 7231 & 7171.2 & 1409.9 \\
\hline & \multirow{7}{*}{$\begin{array}{l}\text { Customer's } \\
\text { Satisfaction } \\
\qquad(0.338)\end{array}$} & Numbers of customers & $\% 192$ & 4853512 & 3440227 & 137563 \\
\hline & & Numbers of cash machines & $\% 142$ & 176 & 650 & 63 \\
\hline & & $\begin{array}{l}\text { Numbers of storable and } \\
\text { banking cash machines }\end{array}$ & $\% 100$ & 120165 & 944885 & 0 \\
\hline & & $\begin{array}{l}\text { Numbers of telephone bank and } \\
\text { SMS users }\end{array}$ & $\% 140$ & 390576 & 304456 & 42779 \\
\hline & & Numbers of bank cards & $\% 168$ & 4717858 & 3401630 & 80870 \\
\hline & & Numbers of internet-bank users & $\% 120$ & 74635 & 65640 & 8952 \\
\hline & & $\begin{array}{l}\text { Numbers of branches of } \\
\text { banking system }\end{array}$ & $\% 138$ & 200 & 201 & 72 \\
\hline & \multirow{6}{*}{$\begin{array}{c}\text { Share } \\
\text { of } \\
\text { Market } \\
(0.187)\end{array}$} & $\begin{array}{l}\text { Share of bank for banking } \\
\text { system deposits }\end{array}$ & $\% 317$ & 9.98 & 5.3 & 1.8 \\
\hline & & $\begin{array}{r}\text { Share of bank for given } \\
\text { facilities of banking system }\end{array}$ & $\% 229$ & 3.2 & 3.5 & 1.2 \\
\hline & & $\begin{array}{l}\text { share of bank for bank cards of } \\
\text { banking system }\end{array}$ & $\% 161$ & 7.8 & 5.6 & 0.13 \\
\hline & & $\begin{array}{l}\text { Share of bank for numbers cash } \\
\text { machines }\end{array}$ & $\% 114$ & 1.4 & 5.2 & 0.5 \\
\hline & & $\begin{array}{l}\text { Share of bank for numbers of } \\
\text { storable cash machines }\end{array}$ & $\% 079$ & 16.6 & 13.1 & 0 \\
\hline & & $\begin{array}{l}\text { Share of bank for numbers of } \\
\text { the total branches of banking } \\
\text { system }\end{array}$ & $\% 100$ & 1.15 & 1.17 & 0.4 \\
\hline & \multirow{6}{*}{$\begin{array}{l}\text { Leading } \\
\text { Products } \\
(0.165)\end{array}$} & $\begin{array}{l}\text { Volume of Riyal exported } \\
\text { guarantees }\end{array}$ & $\% 206$ & 22795 & 16455 & 9643 \\
\hline & & $\begin{array}{l}\text { Volume of foreign exchange } \\
\text { exported guarantees }\end{array}$ & $\% 276$ & 71 & 277 & 38 \\
\hline & & $\begin{array}{l}\text { Volume of exported bills of } \\
\text { exchange }\end{array}$ & $\% 179$ & 1310 & 416 & 217 \\
\hline & & $\begin{array}{c}\text { Volume of imported bills of } \\
\text { exchange }\end{array}$ & $\begin{array}{r}\% 14 \\
2 \\
\end{array}$ & 1027 & 1081 & 652 \\
\hline & & Numbers of credit cards & $\% 102$ & 236636 & 285437 & 8601 \\
\hline & & Numbers of gift cards & $\% 095$ & 2650758 & 1987656 & 25494 \\
\hline
\end{tabular}


Table 6. Decision making matrix in growth and learning perspective

\begin{tabular}{|c|c|c|c|c|c|c|c|}
\hline Concept & Factors & & Variables & Weight & Parsiyan & $\begin{array}{l}\text { Eghtesad } \\
\text { Novin }\end{array}$ & KarAfrin \\
\hline \multirow{13}{*}{$\begin{array}{c}\text { Growth } \\
\text { and } \\
\text { Learning } \\
\text { Perspective } \\
\text { (0.122) }\end{array}$} & \multirow{8}{*}{$\begin{array}{c}\text { Ability } \\
\text { of } \\
\text { Employees } \\
(0.417)\end{array}$} & \multirow{3}{*}{$\begin{array}{l}\text { Rate } \\
\text { of } \\
\text { Education } \\
(0.338)\end{array}$} & $\begin{array}{l}\text { The proportion of } \\
\text { MA and higher } \\
\text { employees' to the } \\
\text { total employees } \\
\text { (percentage) }\end{array}$ & $\% 585$ & 4 & 5 & 4 \\
\hline & & & $\begin{array}{c}\text { The proportion of } \\
\text { BA employees' to } \\
\text { the total } \\
\text { employees } \\
\text { (percentage) }\end{array}$ & $\% 337$ & 69 & 82 & 75 \\
\hline & & & $\begin{array}{l}\text { The proportion of } \\
\text { employees' being } \\
\text { lower than BA to } \\
\text { the total } \\
\text { employers } \\
\text { (percentage) }\end{array}$ & $\% 078$ & 27 & 13 & 21 \\
\hline & & \multirow{5}{*}{$\begin{array}{l}\text { Educational } \\
\text { Program }\end{array}$} & $\begin{array}{l}\text { The proportion of } \\
\text { woman } \\
\text { employees' to the } \\
\text { total employees }\end{array}$ & $\% 417$ & 44 & 46 & 45 \\
\hline & & & $\begin{array}{c}\text { The proportion of } \\
\text { man employees' } \\
\text { to the total } \\
\text { employees }\end{array}$ & $\% 583$ & 56 & 54 & 55 \\
\hline & & & $\begin{array}{c}\text { per capita } \\
\text { education of } \\
\text { employees at the } \\
\text { beginning of } \\
\text { employment-hour }\end{array}$ & $\% 433$ & 72.5 & 75.7 & 67 \\
\hline & & & $\begin{array}{c}\text { per capita } \\
\text { education of } \\
\text { employees during } \\
\text { employment- } \\
\text { hour } \\
\end{array}$ & $\% 359$ & 11.4 & 11.7 & 9.7 \\
\hline & & & $\begin{array}{l}\text { The proportion of } \\
\text { educational cost } \\
\text { to the total costs } \\
\text { (percentage) }\end{array}$ & $\% 208$ & 1.4 & 11.25 & 1.1 \\
\hline & \multirow{5}{*}{$\begin{array}{r}\text { Employees } \\
\text { Satisfaction } \\
(0.583)\end{array}$} & & $\begin{array}{c}\text { Mean of } \\
\text { employees' } \\
\text { salaries per year } \\
\text { (million Riyal) }\end{array}$ & $\% 349$ & 135 & 134 & 132 \\
\hline & & & $\begin{array}{l}\text { The proportion of } \\
\text { employees' } \\
\text { salaries' cost to } \\
\text { the total incomes }\end{array}$ & $\% 134$ & 1.7 & 1.66 & 1.6 \\
\hline & & & $\begin{array}{l}\text { Per capita rate } \\
\text { of distributed } \\
\text { rewards among } \\
\text { employees } \\
\text { (million Riyal) }\end{array}$ & $\% 224$ & 16.9 & 14.6 & 16.7 \\
\hline & & & $\begin{array}{c}\text { Percentage of } \\
\text { employees' } \\
\text { increased salaries }\end{array}$ & $\% 156$ & 31 & 27 & 29 \\
\hline & & & $\begin{array}{l}\text { Annual given } \\
\text { facilities to } \\
\text { employees } \\
\text { (million Riyal) }\end{array}$ & $\% 127$ & 320 & 290 & 275 \\
\hline
\end{tabular}


Table 7. Ranking banks by method of TOPSIS

\begin{tabular}{|c|c|c|}
\hline Ranking banks & $\mathbf{C}_{\mathbf{i}}$ & Bank \\
\hline 1 & 0.615868426 & Parsian \\
\hline 2 & 0.599675578 & Eghtesad Novin \\
\hline 3 & 0.333134679 & Kar-Afarin \\
\hline
\end{tabular}

Table 8 . Ranking bank by SAW method

\begin{tabular}{|c|c|c|}
\hline Ranking Bank & $\mathbf{A}^{*}$ & Bank \\
\hline 1 & 0.833124 & Parsiyan \\
\hline 2 & 0.753193 & Eghtesad Novin \\
\hline 3 & 0.531042 & Kar-Afarin \\
\hline
\end{tabular}

Table 9. Rates of s, $r$ and $q$ and ranking banks by method of VIKOR

\begin{tabular}{|c|c|c|c|c|c|}
\hline Ranking & $\mathbf{Q}_{\mathbf{i}}$ & Place & $\mathbf{R}_{\mathbf{i}}$ & $\mathbf{S}_{\mathbf{i}}$ & Bank \\
\hline 1 & 0.25 & 3 & 0.029857 & 0.272403 & Parsiyan \\
\hline 2 & 0.222486 & 1 & 0.021877 & 0.417862 & Eghtesad Novin \\
\hline 3 & 0.927033 & 2 & 0.027528 & 0.762746 & Kar-Afarin \\
\hline
\end{tabular}

Table 10. Final ranking of banks by the method of Borda

\begin{tabular}{|c|c|c|c|c|}
\hline C $\sum$ & KarAfarin & Eghtesad Novin & Parsiyan & Bank \\
\hline 2 & $\mathrm{M}$ & $\mathrm{M}$ & - & Parsiyan \\
\hline 1 & $\mathrm{M}$ & - & $\mathrm{X}$ & Eghtesad Novin \\
\hline 0 & - & $\mathrm{X}$ & $\mathrm{X}$ & Kar-Afarin \\
\hline & 0 & 1 & 2 & \\
\hline
\end{tabular}

As it is noticed, Parsiyan is in the first rank and Eghtesad Novin is in the second rank and Kar-Afarin is in the third rank.

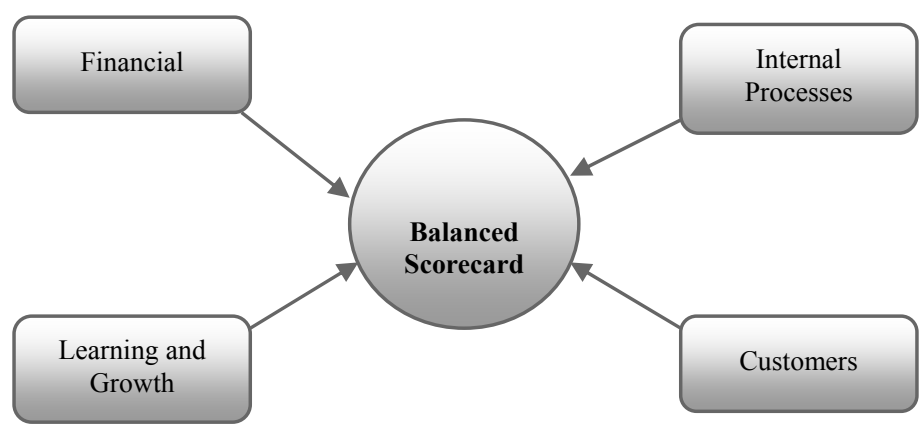

Figure 1. Perspectives of balanced scorecard 


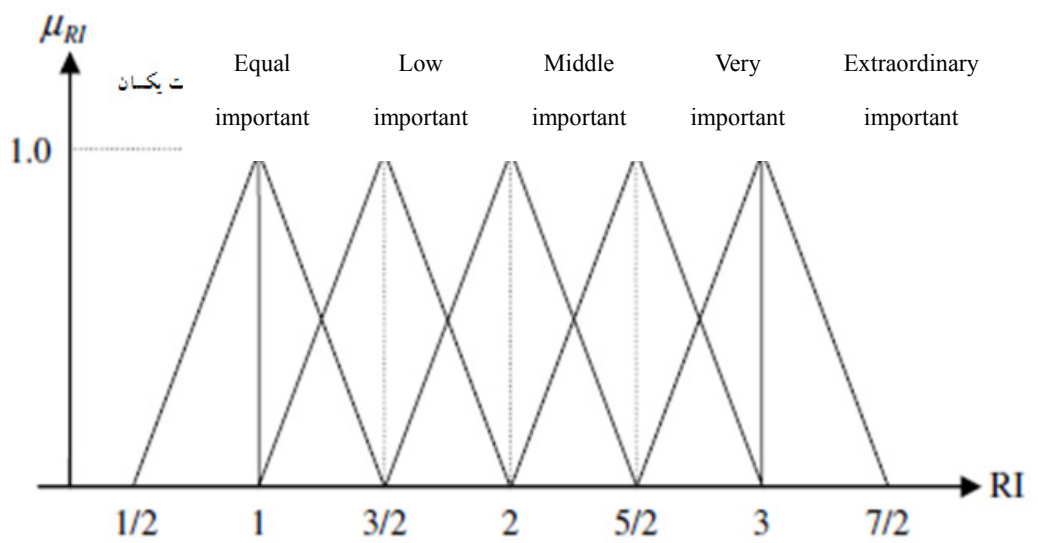

Figure 2. Fuzzy system of quintuple criterion due to convert qualitative criterions to quantitative criterions. 